\title{
Financial Supply Chain Management and Working Capital Management: The Competitive Analysis of HSBC Financial Chain Management
}

\author{
Andrej Agačević ${ }^{1}$, Xu Ming ${ }^{1}$, Syed Ahtsham $\mathrm{Ali}^{1}$ \\ ${ }^{1}$ Glorious Sun School of Business and Management, Donghua University, No. 1882 West Yan'an Road P.O. \\ 200051 Shanghai, China
}

Correspondence: Syed Ahtsham Ali, Glorious Sun School of Business and Management, Donghua University, No. 1882 West Yan'an Road P.O. 200051 Shanghai, China.

Received: November 7, 2018

Accepted: December 10, 2018 Online Published: December 21, 2018

doi:10.5539/ibr.v12n1p65

URL: https://doi.org/10.5539/ibr.v12n1p65

\begin{abstract}
In this paper, a far reaching report on Supply Chain Management (SCM) is displayed. SCM is the administration of a system of interconnected organizations associated with the arrangement of item and administration bundles required by the end clients in a store network. Production network administration traverses all development and capacity of crude materials, work-in-process stock, and completed merchandise from purpose of cause to purpose of utilization. Budgetary Supply Chain Management at Hong Kong and Shanghai Banking Corporation (HSBC) is displayed. Another definition is given by the APICS Dictionary when it characterizes SCM as the "structure, arranging, execution, control, and observing of inventory network exercises with the goal of making net esteem, constructing an aggressive foundation, utilizing overall coordination, synchronizing supply with interest and estimating execution all around." According to late investigations a gigantic measure of working capital is tied up in the Supply Chain. Process-arranged exercises in the Supply Chain, for example, capability, receipt and guarantee administration and back situated exercises, for example, administration of working capital, valorization and capital allocation and request discharge working capital packaged in the Supply Chain. This is acknowledged by a decrease in Days-Sales-Outstanding, which therefore abbreviates the Cash-to-Cash Sequence. Subsequently prompting higher liquidity and expanded investor esteem. Understanding that an enormous potential lies in Financial Supply Chain Management can have the effect between intensity or disappointment, particularly during emergency, as we encounter the Global Financial Disaster.
\end{abstract}

Keywords: working capital, financial suppliers, treasury, settlement and payment, equity offerings, inflation

\section{Introduction}

Supply Chain Management is defined as, "encompasses the planning and management of all activities involved in sourcing and procurement, conversion, and all logistics management activities" (Pfohl H et al; 2000 and Pfohl H et al; 2003). For Hong Kong and Shanghai Banking Corporation (HSBC), the financial year-12 ended with passive economic enactment of the country. The recorded economic growth reach merely to 3.7 percent during the year with 11 percent inflation (Consumer Price Index). The high budget deficits of 6 percent and 1.85 percent has been observed. The federal budget, for financial year 12-13 has been thickly settled in nature with no serious arrangement to those sectors that are not paying taxes or not taxed the least bit. Furthermore, no systematic efforts are being created to rationalize the expenditures of government (Greg Filbeck, et al; 2005). Therefore, the budget deficits and also the associated government borrowing are expected to stay elevated during this financial year. The payment balance scenario is additionally expected to stay under stressed due to the regular payments to the International Monetary Fund. Moreover, the expected continuation of Foreign Direct Investment and foreign portfolio investment flow impair this example. Thus, expected deterioration of the balance of payment position can leave no possibility with the government. However, to approach UN agency for a brand new package inside following six months is an important step.

The positive news for the Islamic Republic of Pakistan economy and customers is that the value of oil and different commodities have declined in international markets. Notably, the government has shared this profit with the customers. This move can contribute to contain inflation. However, unpredictable and enormous government 
borrowing continues to be expected to increase the up inflationary pressures in financial Year 12-13. As a result, we have a tendency to expect inflation and interest rates to maintain at the current levels until end of 2012 if trade goods costs as well as oil remain at this levels. Nonetheless, if an agreement isn't finalized with the United Nations agency by Gregorian calendar month 2012, and also the scale discipline of the govt. doesn't improve; inflation and interest rates are expected to rise and also the Islamic Republic of Pakistan rupee might expertise vital devaluation thanks to deterioration within the balance of payments and exchange reserves position. The Pakistani stock exchange is commercialism at a forward price-to-income of 7.2 times. The historical (last ten years) P/E ratio of the stock exchange is 9.4 times. As a comparison, the P/E ratio of the Bangladesh stock exchange is 12.9 times, and Indian stock exchange is 14.4 times (see Chart 1).

\section{Chart 1}

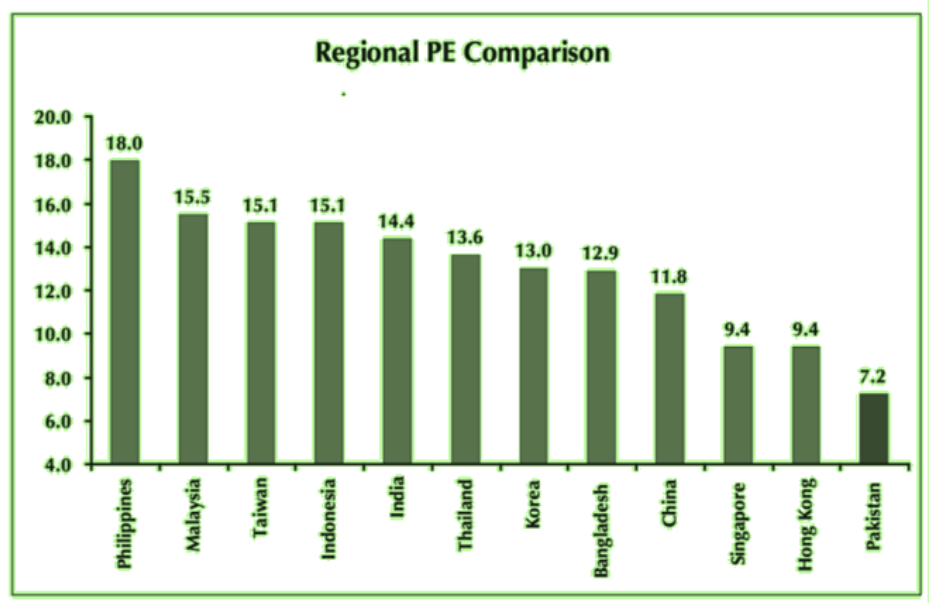

We have a tendency to believe that the Economic and political risks could be already reacted within the stock exchange. Sentiments associated with the approaching elections that can be expected in March 2013 is probably going to present a lift to the stock exchange. Despite muted economic process rate of around 3D p.a. over the last five years, company income have increased by terrorist organization annually throughout a similar amount (see Chart 2). Moreover, executive income area unit expected to rise by August 15 in monetary year-13. we have a tendency to expect the stock exchange to rise in line with company income throughout the monetary year- 13 . Aimed at investors with an investment horizon of over a year we have a tendency to advocate investment within the stock exchange at the current levels.

\section{Chart 2}

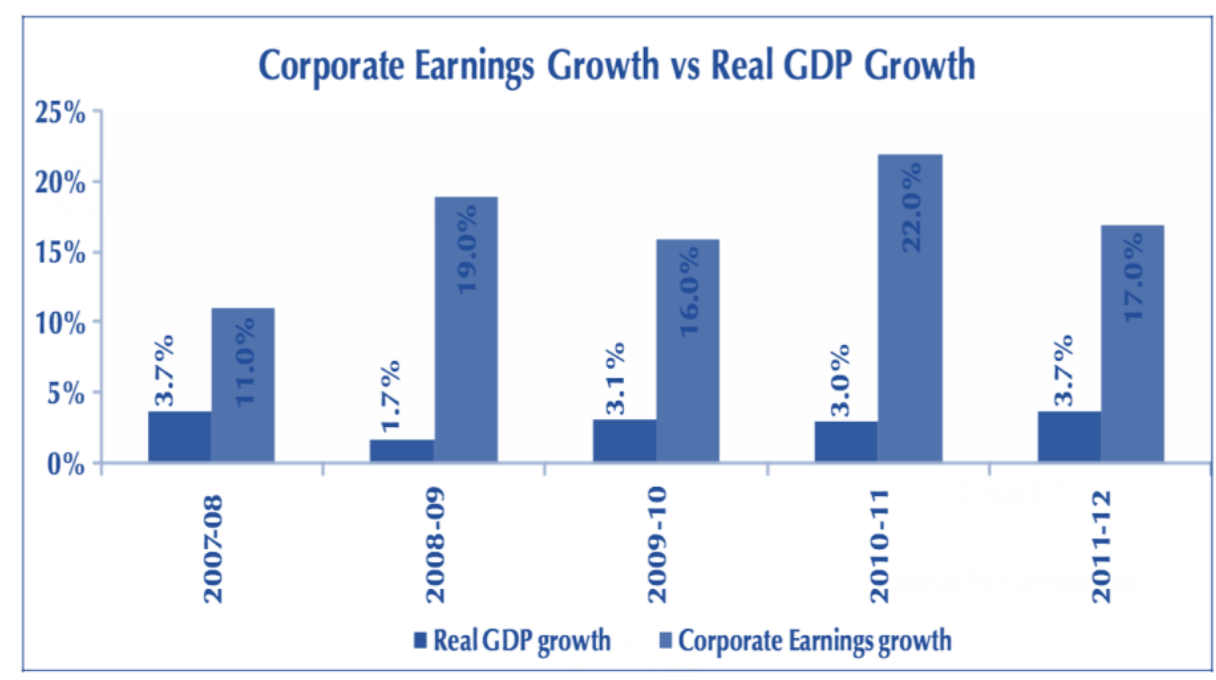




\section{Definition of Supply Chain Management (SCM)}

There are multiple nascent definitions of SCM starting form 80s (Oliver 1995). For this paper, the definition of the Council of provide Chain Management Professionals defines: "SCM encompasses the look and management of all activities concerned in sourcing and procurement, conversion, and every one supply management activities. Significantly, it additionally includes coordination and collaboration with channel partners, which might be suppliers, intermediaries, third party service suppliers, and customers. In principle, SCM assimilates supply and demand management among and across companies" (CSCMP, 2009).

\section{Streams in the Supply Chain Management (SCM)}

In SCM, everything constantly flows due to continuity. SCM is considered to be flow-oriented methodology which link to bring the flow optimization in the Supply Chain with the help of practical and inter-organizational incorporation among the companies Pfohl H et al; 2007 and Simchi 2008).

\section{Financial Supply Chain Management (FSCM)}

FSCM is comparatively new methodology in logistics and recently recognized in literature. Therefore, it's essential to have systematic studies of the various approaches and definitions which are consistent with focus and perspective of FSCM (Presutti WD, et al; 2007 and Rappaport A 1999). The connection among these methodologies is not very clear. The subsequent definitions and methodologies specified by FSCM represent the progressive of science.

\section{Approaches based on Financial Flow}

Roychowdhury, S., (2006) scrutinizes how to Manage the assets and designates numerous tools for upgrading, like improvement of the flow of products and money management. It is established that the improvement potential in assets management for a stronger money performance within the SCM. They described associate degree approach referred to as "Collaborative income Management" which represent financial flows among the SCM actors. Management and improvement of logistics-induced money owes, like inventory management, handling of those flows, as discovered by Schafer H (2002). The approach is considered as supply Chain Finance. Pfohl (2003) designated economic funds within the SCM as FSC which represent the interface between finance and supply.

\section{Problem Statement}

In some of the dynamic market surroundings, formed by constant technical developments and globalization, a state-of-the-art SCM is preponderant. significantly in crisis, as we have a tendency to expertise immediately with the worldwide money crisis, enterprises are required to sustain or maybe augment the profit Shapiro J (1992). Consequently, negative influences on stock costs may be prevented, preserved trustworthiness and secured working capital within the middle and long-standing time. because of Basel II and therefore the crisis, granting credits is a lot of restrictive and therefore the capital market doesn't give quick assets as simply as within the years before Siegwart H (1994). On one hand, quick assets area unit scarce in money crises and on the opposite hand, the wants of Basel II request bound conditions for the credit. Thus companies ought to improve their liquid state of affairs and notice attainable improvement. In keeping with current reports, the immense quantities of assets area unit busy within the provide Chain. money provide SCM is that the key to unleash that assets. However, yet money provide Chain Management isn't renowned to subjects of business. The most reason is, that money aspects area unit allotted to finance and to not SCM. thus far provide The physical perspective of the chain management has been observed, with the intention to improve flows of products and data so as to form price. it's of essential importance that this recent read is supplemented by a money purpose of read by that specialize in the money flows on the provision Chain to boost investor price. specialists claim that the improvement potential of monetary aspects is capable that of the physical aspects within the provide Chain. thus managing the provision Chain economically, thus referred to as money SCM, will considerably improve liquidity and investor price. some extent of criticism against money SCM is, that parallel and aged analysis concerning the utilization of ratios in SCM, for example DCF and EVA technique, area unit printed with reference to provide Chain dominant. Authors, like Simchi L.D., et al., (2008), Skiera B, et al; (2004), and Skinner, D. et al., (2002) highlighted the prominence of SCC tool to attain extraordinary in operation profit to boost company profit. Certainly, this situation is in accordance with the FSCM. Nonetheless, no classification between SCC and FSCM may be found in literature.

\section{Objectives}

This Paper aims at outlining the importance of FSCM as a tool to extend share owner price. The major goal is to mirror how monetary flows within the price chain is optimized so as to boost price of stakeholder. This results in the subsequent analysis questions: What's the worth proposition of FSCM? How financial flows are optimized? How FSCM can be improved? How international companies offer FSCM? 


\section{Discussions}

\section{Financial- SCM Connection Model}

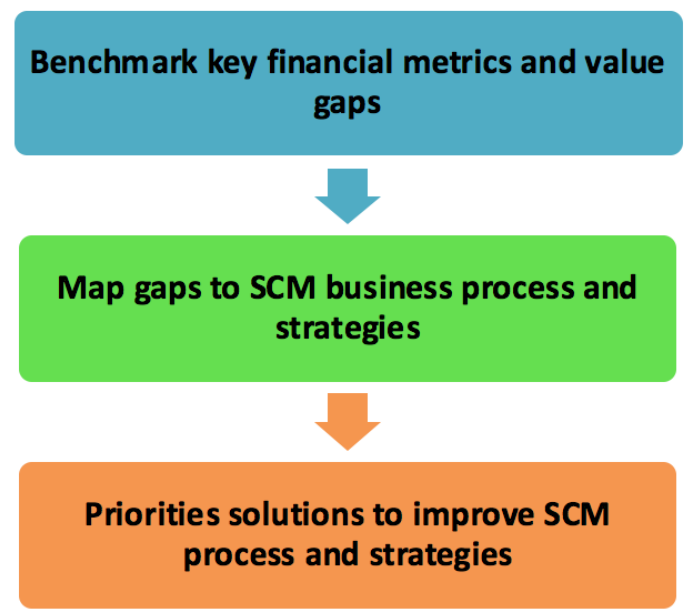

SCM can bring the positive influence on the company growth, profitability and capital utilization by considering few points. SCM policies and the decisions should be made from company's wider viewpoint. There is need to identify the gaps/loop holes in the financial metrics, which can also serve as a motivation to bring the change Xinhan $\mathrm{Xu}$ et al (2018). There is need to investigate the gaps in business processes related to SCM, such as, distribution and logistics, forecasting, demand planning. Importantly the business processes' gaps are linked to the activities and tasks.

Our paper consists of two streams of research

- Real income management

- Income management around seasoned equity offerings (SEOs)

\subsection{Accrual-Based Income Management}

Initiating with Teoh (1998), investigators are involved about the corporations manage rumored income throughout seasoned equity offerings, and also the accounting and exchange consequences related to such accomplishments. Thus we are motivated by the empirical discoveries that seasoned equity offerings area unit followed by each poor stock returns and underprivileged performance income. This result in having suspect about the income that how they are managed to move upward which could be linked in anticipating the seasoned equity offerings, and later reverse (For example, Xu, R.Z., et al., (2007). The positive abnormal accruals were found, on the average for seasoned equity offerings corporations throughout the year round the SEO. The findings are interrupted to the mean that the companies achieve upward income around seasoned equity offerings, which the exchange is misled by the up managed income, briefly overvaluing issue corporations then being frustrated by their foreseeable income declines, that cause their stock costs to later fall. Teoh (1998) stated more or less comparable proof, by adding an additional discovery that seasoned equity issuers offerings Their clarification is that the similar to the Rangan (1998). Later on, Shivakumar (2000) additionally discovers the proof per accruals income management about seasoned equity offerings. However, in distinction to above both authors, he demonstrated that the exchange doesn't react incompetently to the up managed income, however this action is undo rationally by the investors. The qualities explained by Rangan's and Teoh are also attributed by him about their findings of irregular returns in the stock to check the discontinuity. Difference of opinion that the income management isn't intended to dupe or mislead the investors, however is itself considered to be a rational reaction about the anticipation of the market that corporations can manage remunerations round the seasoned equity offerings. Seasoned equity offerings and the income management is basically a part of a bigger literature which deals with focus on finding the income management with a link to the company's actions such as management buyouts, stock acquisitions, and stock repurchases.

\subsection{Real Income Management}

Though real income management has not been as wide studied as accrual- primarily based income management, Graham (2005) found that managers like real activities, by such means reducing the expenditures or capital 
investments, over accruals manipulation as the simplest way to manage the income. These real income management activities are considerably totally different than accumulation -based ones as they need direct money flows effects. Graham et al. (2005) find

Strong proof that managers consider to take is basically the actual economic activities to preserve the accounting appearances. According to one survey, most of the participants think that they'd like to reduce the flexible expenditure on Research and Development, advertising. And will try to maintain or achieve the income goal. In the survey more than 55.3\% think that they'd pause the beginning a brand new project to fulfill the income goal, even though this type of delay may also be called as sacrifice in value of the company"

Due to minimum 2 reasons, the executives suffers from bigger temperament to manage the target of income using real time activities rather than accruals. Primarily, the accrual-based income management is additional doubtless to attract auditor or regulative scrutiny as compared to the real choices. Secondly, the counting on accruement maneuvering solely is also risky. The completed deficit concerning the unmanaged income and also the anticipated threshold will surpass the quantity by that it's doable to control accruals when the tip of the business enterprise amount. Accordingly, the financial gain drops below the brink, in that case accrual-based ways to satisfy it are shattered. As a result, the managers are left with no choices as a result of real activities can't be adjusted at or when the tip of the business enterprise reportage amount.

If we focus on the zero income limit and try to examine the annual knowledge, the companies try to avoid reportage losses in 3 different ways, which are described below:

1) Firstly, the sales can be boosted through fast their temporal order and by generating extra unsustainable sales, or doing both at the same time. This is done through inflated worth reductions or additional soft terms of credit

2) Secondly, by overproducing and by assigning additional operating cost to the inventory and fewer to value of products sold-out, that ends up in lower value of products sold-out and inflated margins of operation

3) Thirdly, by sharply decreasing the expenses to enhance the margins, which is possibly to happen once such optional expenses don't generate instant revenues.

Zang et al; (2012) examines the tradeoffs among the accruement handlings and the real income management. They suggested that the choices to manage income through "real" actions precede choices to manage income through accruals. Her results show that real manipulation is completely correlative with the prices of accruement manipulation, which accruement and real manipulations are negatively correlative. These findings lead her to conclude that managers treat the 2 ways as substitutes. In connected analysis, sacking (2005) examines the implications of real income management and finds that it encompasses significant negative impact on upcoming operative implementation. to boot, it seems that capital markets contributors largely acknowledge the longer term incomes suggestions of managers' bigoted performances.

\subsection{Real Income Management in the post-Sarbanes -Oxley Act (SOX) Period}

Current analysis on real income management in the post- Sarbanes -Oxley Act (SOX) centered on evaluating the economic concerns of the Sarbanes -Oxley Act (SOX), questionably "the utmost extensive reforms of yank business practices since the time of Franklin D. Roosevelt. One amongst the fascinating problems that are addressed within the literature is whether or not income management overall and therefore the mixture of ways have modified considerably within the post SOX amount. particularly, as Graham, et al. (2005) estimation:

the resultant of accounting scandals at Enron and World Com and therefore, the certification needs obligatory by the Sarbanes-Oxley Act could have modified the managers'likings for the combo among the taking accounting versus the real actions to accomplish income goals.

To analyze the tendencies in income management practices within the pre and post Sarbanes -Oxley Act, Cohen (2007) notice that the companies swapped from accrual based to the real income management. They described that companies that simply achieved necessary incomes standards used fewer accruals and additional real income management methods once Sarbanes -Oxley Act in comparison to similar companies before Sarbanes -Oxley Act. The apparent modification in social control behavior with relation to the choice methods utilized to manage reportable income once Sarbanes -Oxley Act motivates North American nation to look at whether or not any such modification is often determined for companies that are participating in seasoned equity offerings. Specifically, we tend to request to grasp whether or not companies participating in SEOs within the post- Sarbanes -Oxley Act amount use totally different income management tools as compared to the pre - Sarbanes -Oxley Act amount. The 
Sarbanes -Oxley Act regulation may be a natural setting to perform this sort of experiment, because it is thought to be an exogenous shock moving all the companies within the North American nation economy.

In short, there's sturdy proof of real income management actions, which are attained via multiple recommendation that, and it's possible joined to meeting bound income standards. Therefore, we tend to initial request to look at whether or not real income management activities are used as income management tools around seasoned equity offerings and whether or not there exists any substitution or complementary relation with accrual-based methods. Aligned with the literature, we tend to additionally examine the following performance following seasoned equity offerings as a operate of the income management vehicle used round the year of the seasoned equity offerings. Our second purpose is to analyze the seasoned equity offerings firms' selection of income management tools has modified from the pre- Sarbanes -Oxley Act to the post- Sarbanes -Oxley Act amount. Finally, we tend to examine the cross-sectional factors of the alternatives companies build between the totally dissimilar income management actions around seasoned equity offerings, to raised perceive why bound companies can select totally different income management kits round the year of the seasoned equity offerings.

\section{Empirical Methodology}

Our seasoned equity offerings sample contains of one, 511 completed U.S. offers over the 1987 to 2006 amount, and is obtained from the Securities Information Company (SDC) The sample criteria needs seasoned equity offerings to be problems with common stocks by U.S. issuers that square measure listed on New York Stock Exchange, NASDAQ, or stock exchange and eliminate the subsequent few things:

(1) seasoned equity offerings missing COMPUSTAT yearly plan information for the four years before seasoned equity offerings date of filing, thus provide year and also the future year,

(2) accomplished seasoned equity offerings with provide costs but $\$ 5$ and withdrawn SEOs with filing vary center but $\$ 5$,

(3) offshoots,

(4) converse LBOs

(5) endowment unit investment trusts REITS and restricted businesses

(6) problems of rights

(7) synchronous or joint suggestions of many categories of safeties

(8) non-domestic and synchronous domestic international proposals.

Based on above points, the money information was collected from the COMPUSTAT annual industrial and analysis. And we tend to limit our sample to any or all commercial enterprise companies with offered information, and need a minimum of eight observations in every 2-digit assault grouping annually. Further, we tend to need that every firm- year surveillance has the related info needed to compute and analyze the discretionary accruals metrics. The as-mentioned restriction probably presents a survivorship bias into the sample leading to the inclusion of larger and a lot of prospering companies. we tend to expect that this can scale back the variation in our income management metrics leading to a lot of conservative take a look at of our analysis queries. Subsequently, Collins and Hribar (2002), tend to use money flows taken from the operations got from the Statement of money Flows according beneath the Statement of monetary Accounting Standards No. 95. The sample amount of 1987-2006 permits USA to use SFAS No. 95 statement of money flow information to guess accruals, instead of a record method. Panel A provides outline data on the dimensions and providing characteristics. in step with previous studies (like Teoh 1998 and Rangan, 1998), our sample of seasoned equity offerings companies tends to own high book- to-market ratios, averaging around 2.5. this can be not stunning, since companies tend to issue equity once valuations square measure high. Average provide size is concerning $1 / 4$ of pre-offer market price. Panel B shows the distribution of seasoned equity offerings over time. Also, in step with previous analysis, there's your time cluster, as several seasoned equity offerings occurred throughout the 1990's. for instance, throughout 91-99. 879 out our total sample of 10511 seasoned equity offerings (58\%). this can be conjointly not stunning, since the securities market boomed throughout this era, and equity estimates were considered to be in excess. Meanwhile the market older a major worsening starting in start of $20^{\text {th }}$ century. there are rarer seasoned equity offerings. Panel C reports the frequency of seasoned equity offerings by business and indicates that whereas seasoned equity offerings abundantly occur in alternative forms of businesses, throughout our sample amount they were particularly common in engineering areas as chemical merchandise, laptop instrumentation, tools, and electronic services. Altogether, the as-mentioned four companies encompass quite four-hundredth of the sample once more, this finding isn't stunning, because the high school fields semiconductor diode the 90s securities market boom. In short, 
the as-described sample displays very much comparable features to the samples discussed in earlier seasoned equity offerings analysis, indicating that seasoned equity offerings square measure clustered each in time by various comapnies.

\section{Income Management Metrics}

By using cross-sectional model about the discretionary accruals, wherever for every year, the researchers tend to evaluate the model for each specific business. This was mostly classified by its two-digit attack code. Therefore, our method partly regulates for industry-wide changes in economic circumstances that have an effect on total accruals whereas permitting the coefficients to vary across time (Kasznik, 1999; DeFond and Jiambalvo, 1994). we tend to get qualitatively an equivalent result once we use a time-series approach that assumes temporal stationarity of the parameters for every firm. Our primary model is that the changed cross -sectional Jones model (Jones 1991) as represented in Dechow (1995).

\section{Summary}

In this paper, a report on Supply Chain Management (SCM) is displayed which is considered an administration of a system of interconnected organizations associated with the arrangement of items. In SCM, the production network administration traverses all development and capacity of crude materials, work-in-process stock, and completed merchandise from purpose of cause to purpose of utilization. Budgetary Supply Chain Management at HSBC is displayed. According to late investigations a gigantic measure of working capital is tied up in the Supply Chain. Process-arranged exercises in the Supply Chain, for example, capability, receipt and guarantee administration and back situated exercises, for example, administration of working capital, valorization and capital allocation and request discharge working capital packaged in the Supply Chain. This is acknowledged by a decrease in Days-Sales-Outstanding, which therefore abbreviates the Cash-to-Cash Sequence. Subsequently prompting higher liquidity and expanded investor esteem. Understanding that an enormous potential lies in FSCM may have the effect between intensity or disappointment, particularly during emergency, as we encounter the Global Financial Disaster. On this basis, the organization needs to clarify the responsibilities by determining who sets and who monitors payments and decide how much these activities should be centralized. Besides this, it is important to define the strategy. Decide between the single and the portfolio approach and, as the case may be, detail each strategy (payment terms, negotiation priorities, tools).

\section{References}

Greg, F. et al. (2005). An Analysis of Working Capital Management Results Across Industries. American Journal of Business, 20(2), 11-20. https://doi.org/10.1108/19355181200500007

Pfohl, H. et al. (2000). Supply Chain Management: Logistik Plus? Logistikkette - Marketingkette - Finanzkette, Book chapter Supply Chain Management: Konzepte, Trends, Strategien., pp. 3\{37. Erich Schmidt Verlag, Berlin, Germany. ISBN 978-3-503-05889-1.

Pfohl, H. et al. (2003). Financial Supply Chain Management - Neue Herausforderungen fur die Finanz- und Logistikwelt." Logistik Management, 5(10), 26.

Pfohl, H. et al. (2007). Die Supply Chain Finance Gesellschaft." Industries Management, 23(11), 14.

Presutti, W. D. et al. (2007). The Supply Chain-Finance Link. Supply Chain Management Review, 11, 32-38.

Rappaport, A. (1999). Shareholder Value. Ein Handbuch for Manager und Investoren. Scha_er-Poeschel, Stuttgart, Germany, 2nd edition. ISBN 3-7910-1374-2.

Roychowdhury, S. (2006). Earnings management through real activities manipulation. Journal of Accounting and Economics, 42(3), 335-370. https://doi.org/10.1016/j.jacceco.2006.01.002

Schafer, H. (2002). Unternehmens_nanzen \{Grundzuge in Theorie und Management. Physica Verlag, Heidelberg, Germany, 2nd edition. ISBN 3-79081492-X.

Shapiro, J. (1992). Integrated Logistics Management, Total Cost Analysis and Optimization Modelling. The International Journal of Physical Distribution and Logistics Management, 22, 33-36. https://doi.org/10.1108/EUM0000000000414

Shell. (2009). Homepage Royal Dutch Shell plc." [Online; accessed 9-April2009], http://www.shell.com. Siebert J, Strohmeier M (2006). MySAP ERP Financials. Galileo Press, Bonn, Germany. ISBN 978-3-89842-746-3.

Siegwart, H. (1994). Der Cash Flow als _nanz- und ertragswirtschaftliche Lenkungsgr osse. Scha_er-Poeschel, Stuttgart, Germany, 3rd edition. ISBN 3-8202-0894-1.

Simchi, L. D. et al. (2008). Designing and Managing the Supply Chain: Concepts, Strategies and Case Studies. 
Irwin McGrawHill, Boston, USA, 3rd edition. ISBN 978-0-07-110750-1.

Skiera, B, et al. (2004). Financial Chain Management - Prozessanalyse, E_zienzpotentiale und Outsourcing. Books on Demand GmbH, Norderstedt, Germany. ISBN 3-8334-1340-9.

Skinner, D. et al. (2002). Earnings surprises, growth expectations, and stock returns or don't let an earnings torpedo sink your portfolio. Review of Accounting Studies, 7(2-3), 289-312. https://doi.org/10.1023/A:1020294523516

Xinhan, X. et al. (2018). Supply chain finance: A systematic literature review and bibliometric analysis. International Journal of Production Economics, 204, 160-173. https://doi.org/10.1016/j.ijpe.2018.08.003

Xu, R. Z. et al. (2007). Review of Real Earnings Management Literature. Journal of Accounting Literature, 26, 195-228.

Zang, A. Y. (2012). Evidence on the trade-off between real activities manipulation and accrual- based earnings management. The Accounting Review, 87(2), 675-703. https://doi.org/10.2308/accr-10196

\section{Copyrights}

Copyright for this article is retained by the author(s), with first publication rights granted to the journal.

This is an open-access article distributed under the terms and conditions of the Creative Commons Attribution license (http://creativecommons.org/licenses/by/4.0/). 